\title{
Antiphytoviral Activities of Turbinaria Conoides (J. Agardh) Kutzing
}

\author{
*Poonam Sethi \\ Assistant Professor, Guru Nanak College. Chennai,India.
}

\begin{abstract}
Turbinaria conoides (J. Agardh) Kutzing, (Phaeophyceaee) a marine seaweed, abundant in the shores of Kanyakumari, India during the month of April, was tested for activity against Tobacco necrotic virus $(T N V)$. Local lesion method was adopted and half leaf comparisons were made in cotyledonary leaves of Cyamopsis tetragonoloba Taub.(Linn.).Extracts of the experimental algae prepared with water, methanol and toluene: methanol $(2: 1 \mathrm{v} / \mathrm{v})$, were tested for antiviral activity against the plant virus TNV. Various concentrations were tested and the toluene: methanol exhibited good activity at a concentration of $1000 \mu \mathrm{g} / \mathrm{mL}$ and reduced the number of lesion formed by TNV by nearly $64 \%$. These results clearly depict the potential of the algae.
\end{abstract}

Key words: Turbinaria, Cyamopsis, phytoviral, Tobacco necrotic virus.

\section{Introduction}

The recent increase in compounds isolated from land plants, has open doors to the poorly exploited marine ecosystem which appears to be a good candidate of natural resource [Baker ,1984]. The aquatic ecosystem covers about $70 \%$ of the earth's surface and India has a vast coastline of $6100 \mathrm{~km}$ supporting a rich flora of marine plants such as seaweeds, mangroves and sea grasses [Chapman \&Chapman,1980]. As a part of our ongoing research a natural source providing mankind with various secondary metabolites having activity against viruses, which provides a new way for control of plant virus diseases. Marine algae exhibit interesting nutritional properties in addition to their ecological properties. The results of the study suggest that the algae which are abundantly available in this ecosystem also have considerable potential of carbohydrates, amino acids, proteins, phenols and lipids for their use as food and pharmaceutical industry as a source in preparation of nutrient supplements, medicine and fine chemical synthesis. As suggested by [Jamieson and Reid, 1972] the efficacy of lipid extracts was tested hence toluene :methanol extracts were used.

\section{Materials And Method}

Local strain of the TNV (Tobacco Necrosis Virus) were obtained from Madurai Kamaraj University, Tamil Nadu. The procedures outlined by [Caccamese et al.,1981] were followed in the assay. Seeds of Cyamopsis tetragonoloba Taub.(Linn.) var. Navbahar were purchased from a government certified seed centre and surface sterilized with $0.1 \%$ acidified mercuric chloride for 3 to 5 minutes. The seeds were then sown in sterilized soil and grown in earthen pots.

Alga was collected from shores of Kanyakumari, India and identified, authenticated by Dr. R. Thevanathan, Presidency College, Chennai. It was then shade dried and ten grams of the dried alga was extracted with $100 \mathrm{~mL}$ of the solvents double distilled water, methanol and toluene : methanol, 2:1 v/v and later kept in a shaker for 48 hours. The three extracts were then filtered through Whatman No.1 filter paper and dried in an oven at $40^{\circ} \mathrm{C}$. The residues obtained were then weighed and stored at $4^{\circ} \mathrm{C}$ and used for the antiviral assay. The inoculum was prepared by grinding $1.0 \mathrm{~g}$ of virus-infected cotyledonary leaves, the sap strained through cheese cloth, celite was added as an abrasive at the rate of $2 \mathrm{mg} / \mathrm{mL}$. Inoculation was carried out by rubbing the leaves from the base of the leaf towards the tip with the forefinger previously dipped in the inoculum. The readings were taken on the basis of dark green spots of $1 \mathrm{~mm}$ diameter which developed as a result of infection through inoculation were observed at every 24 hour interval. The intensity of the viral infection was scored after 72 hours based on the number of lesions formed.

The extract residues of the experimental algae were weighed and dissolved in $0.25 \%$ DMSO (Dimethyl sulphoxide) to obtain $1.0 \mathrm{mg} / 1.0 \mathrm{~mL}$ concentrations. From this solution, $1: 10$ water dilutions were made and the inhibitory effect of these solutions were tested against tobacco necrosis virus (TNV) on the cluster bean plant, Cyamopsis tetragonoloba.

Inoculations were performed on 9-day old cotyledonary leaves all the tests were made in replicates of ten, and half-leaf comparisons were made. The experimental half-leaves were inoculated with known concentrations of the extract and virus suspension. The plants were monitored for 72 hours and the number of local lesions induced by TNV was estimated using the following formula inhibition $=\mathrm{A}-\mathrm{B} / \mathrm{A} \times 100$ 
where, control-A, experimental-B

Inhibition is based on the reduction of the number of local lesions induced by TNV, in the absence (A) or the presence (B) of the algal extract. programme.

Results were analysed for statistical significance using SPSS (Statistical Package for Scientific Studies)

\section{Results And Discussion}

Extracts of the experimental algae prepared with water, methanol and toluene: methanol $(2: 1 \mathrm{v} / \mathrm{v})$ were tested and toluene: methanol were best in comparison to water and methanol extracts against the plant virus. The effect of the extract residues on TNV are given in Table1. At a concentration of $1000 \mu \mathrm{g} / \mathrm{mL}$, the toluene: methanol extract residue of Turbinaria was able to reduce the lesion formation by nearly $64 \%$.

At a concentration of $1.0 \mu \mathrm{g} / \mathrm{mL}$, the active fraction of toluene: methanol extract residue, could reduce the formation of lesions by nearly $44 \%$. Increasing the concentration of the residue from $1.0 \mu \mathrm{g} / \mathrm{mL}$ to 10 $\mu \mathrm{g} / \mathrm{mL}$ and $100 \mu \mathrm{g} / \mathrm{mL}$, the percent reduction in lesion formation by TNV was enhanced by $14 \%$ respectively However, at a concentration of $1000 \mu \mathrm{g} / \mathrm{mL}$, the reduction in lesion formation was $64 \%$.Earlier it was reported that the methanolic extracts of brown algae when assayed against Potato virus $\mathrm{X}$ inhibited the infectivity by more than $80 \%$ [Pardee et al.,2004], contradictory to this brown alga was active against the virus with toluene: methanol $(2: 1 \mathrm{v} / \mathrm{v})$ than methanol, Organic extracts obtained from the brown-alga Lessonia trabeculata inhibited bacterial growth and reduced both the number and size of the necrotic lesion in tomato leaves following infection with Botrytis cinerea whereas aqueous and ethanolic extracts from the red-alga Gracillaria chilensis prevent the growth of Phytophthora cinnamomi, showing a response which depends on doses and collecting-time. Similarly, aqueous and ethanolic extracts from the brown-alga Durvillaea antarctica were able to diminish the damage caused by tobacco mosaic virus (TMV) in tobacco leaves[Edra Jiménez et al.,2011], not much work has been done on Turbinaria conoides a phaeophycean or brown alga hence the reports with the world's worst invasive species being highly active against necrotic virus was the first one. Thus it is a promising antiphytoviral agent.

\section{References}

[1]. Baker, J. (1984) Seaweed in pharmaceutical studies and applications. Hydrobiologia 116/117: 29-40.

[2]. Caccamese, S., Azzolina, R., Furnari, G., Cormaci, M. and Grasso, S. (1981) Antimicrobial and antiviral activities of some marine red algae from Eastern Sicily. Bot. Mar. 24: 365 - 367.

[3]. Chapman, V. J. and Chapman, D. J. (eds). (1980) Seaweeds and their uses. $2^{\text {nd }}$ ed. Chapman \& Hall, New York pp.1-334.

[4]. Edra Jiménez, Fernando Dorta , Cristian Medina, Alberto Ramírez, Ingrid Ramírez and Hugo Peña-Cortés. (2011) .AntiPhytopathogenic Activities of Macro-Algae Extracts. Mar. Drugs. 9, 739-756.

[5]. Jamieson, G. R. and Reid, E. H. (1972) The component fatty acids of some marine algal lipids. Phytochemistry 11: 1423 - 1432

[6]. Pardee, K. I., Ellis, P., Bouthillier, M .and Towers, G. H.N. C. J . (2004).French Plant virus inhibitors from marine algae. Canadian Journal of Botany. 82(3): 304-309.

[7]. Smith, K. M. (1957) A Text Book of Plant Virus Diseases. $2^{\text {nd }}$ Ed. Little Brown, Boston, Massachusetts.

Tables

Table - 1 Effect of the Crude Extract Residue of the Experimental Algae on Lesion Formation by TNV on the Leaves of Cyamopsis tetragonoloba

\begin{tabular}{|c|c|c|c|}
\hline Extract & $\begin{array}{c}\text { Varying } \\
\text { Concentrations of the } \\
\text { Crude Extract } \\
\left.(\mu \mathrm{g} \mathrm{mL})^{-1}\right)\end{array}$ & $\begin{array}{l}\text { Mean of Number } \\
\text { of Lesions } \pm \text { SE }\end{array}$ & $P$ Value \\
\hline AQUEOUS & $\begin{array}{l}\text { Control } \\
1 \\
10 \\
100 \\
1000\end{array}$ & $\begin{array}{c}22.07 \pm 0.92 \\
20.60 \pm 0.77 \\
16.90 \pm 0.91 \\
10.60 \pm 0.24 \\
10.90 \pm 0.45\end{array}$ & $\begin{array}{l}0.000 \\
0.070 \\
0.000 \\
0.000 \\
0.000\end{array}$ \\
\hline METHANOL & $\begin{array}{l}\text { Control } \\
1 \\
10 \\
100 \\
1000 \\
\end{array}$ & $\begin{array}{l}22.32 \pm 0.05 \\
19.25 \pm 0.4515 .20 \\
\pm 0.10 \\
12.70 \pm 0.29 \\
11.40 \pm 0.56 \\
\end{array}$ & $\begin{array}{l}0.000 \\
0.003 \\
0.000 \\
0.000 \\
0.000\end{array}$ \\
\hline $\begin{array}{l}\text { TOLUENE : METHANOL, } 2: 1 \\
\text { V/V }\end{array}$ & $\begin{array}{l}\text { Control } \\
1 \\
10 \\
100 \\
1000\end{array}$ & $\begin{array}{l}22.32 \pm 0.05 \\
14.25 \pm 0.4512 .20 \\
\pm 0.10 \\
11.70 \pm 0.29 \\
09.40 \pm 0.56\end{array}$ & $\begin{array}{l}0.003 \\
0.000 \\
0.000 \\
0.000 \\
0.001\end{array}$ \\
\hline
\end{tabular}


Plate I: Cotyledonary leaves of Cyamopsis tetragonoloba showing TNV induced lesion

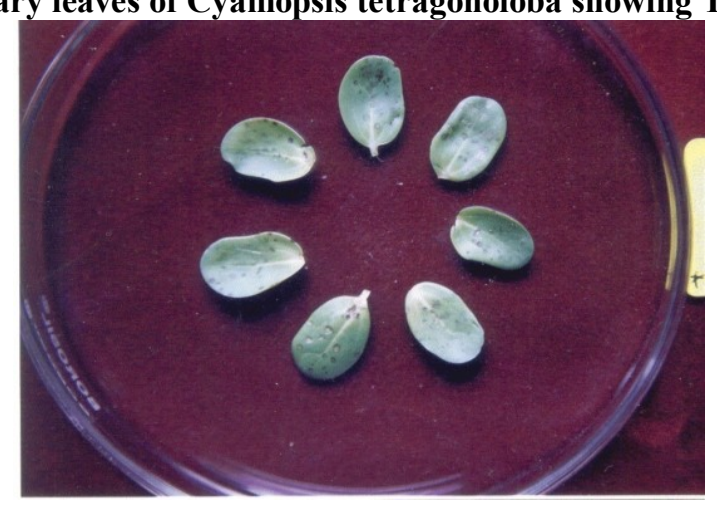

